\title{
Microcystin-LR induces mitochondria-mediated apoptosis in human bronchial epithelial cells
}

\author{
YANG LI ${ }^{1}$, JINHUI LI ${ }^{2}$, HUI HUANG ${ }^{1}$, MINGFENG YANG ${ }^{1}$, DONGGANG ZHUANG ${ }^{1}$, \\ XUEMIN CHENG ${ }^{1}$, HUIZHEN ZHANG ${ }^{1}$ and XIAOLI FU ${ }^{1}$ \\ ${ }^{1}$ College of Public Health, Zhengzhou University, Zhengzhou, Henan 450001; \\ ${ }^{2}$ Henan Science and Technology Exchange Center with Foreign Countries, \\ Zhengzhou University, Zhengzhou, Henan 450003, P.R. China
}

Received May 21, 2015; Accepted April 11, 2016

DOI: $10.3892 /$ etm.2016.3423

\begin{abstract}
The present study aimed to investigate the toxicity of microcystin-LR (MC-LR) and to explore the mechanism of MC-LR-induced apoptosis in human bronchial epithelial (HBE) cells. HBE cells were treated with MC-LR (1, 10, $20,30$ and $40 \mu \mathrm{g} / \mathrm{ml})$ alone or with MC-LR $(0,2.5,5$ and $10 \mu \mathrm{g} / \mathrm{ml})$ and Z-VAD-FMK $(0,10,20,40,60,80,100,120$ and $140 \mu \mathrm{M})$, which is a caspase inhibitor, for 24 and $48 \mathrm{~h}$. Cell viability was assessed via an MTT assay and the half maximal effective concentration of MC-LR was determined. The optimal concentration of Z-VAD-FMK was established as $50 \mu \mathrm{m}$, which was then used in the subsequent experiments. MC-LR significantly inhibited cell viability and induced apoptosis of HBE cells in a dose-dependent manner, as detected by an Annexin V/propidium iodide assay. MC-LR induced cell apoptosis, excess reactive oxygen species production and mitochondrial membrane potential collapse, upregulated Bax expression and downregulated B-cell lymphoma-2 expression in HBE cells. Moreover, western blot analysis demonstrated that MC-LR increased the activity levels of caspase- 3 and caspase- 9 and induced cytochrome $c$ release into the cytoplasm, suggesting that MC-LR-induced apoptosis is associated with the mitochondrial pathway. Furthermore, pretreatment with Z-VAD-FMK reduced MC-LR-induced apoptosis by blocking caspase activation in HBE cells. Therefore, the results of the present study suggested that MC-LR is capable of significantly inhibiting the viability of HBE cells by inducing apoptosis in
\end{abstract}

Correspondence to: Professor Huizhen Zhang or Professor Xiaoli Fu, College of Public Health, Zhengzhou University, 100 Kexue Avenue, Zhengzhou, Henan 450001, P.R. China

E-mail: huizhen18@126.com

E-mail: fuxiaoli118@126.com

Abbreviations: HBE, human bronchial epithelial cell; MTT, 3-(4,5-dimethylthiazol-2yl)-2,5-diphenyltetrazolium bromide; DCFH, 2',7'-dichlorofluorescein; mcs, microcystins

Key words: microcystin-LR, human bronchial epithelial cell, apoptosis, mitochondria a mitochondria-dependent manner. The present study provides a foundation for further understanding the mechanism underlying the toxicity of MC-LR in the respiratory system.

\section{Introduction}

Cyanobacterial blooms remain a global burden, due to the production of cyanotoxins (1). An outbreak of cyanobacterial blooms induces the release of microcystins (MCs) into water, and is a serious threat to aquatic organisms, wildlife and humans that ingest the toxins from cyanobacteria or water aquatic ecosystems (2). MCs are a group of $>100$ cyanobacterial toxin variants, of which MC-LR is the most common variant and the most potently toxic peptide (3). Furthermore, it has previously been reported that MC-LR is highly hepatotoxic and is a liver tumor-specific promoter (4).

MCs are a group of highly stable environmental pollutants that are not readily hydrolyzed or oxidized at normal $\mathrm{pH}$, thus, they may survive for months to several years (5). Toxins released into the water from broken algal cells are a threat to human health through skin contact, inhalation, hemodialyses and oral ingestion. It has been reported that MCs may cause damage to the respiratory system (6); however, the associated mechanism has yet to be elucidated. Incidents involving poisoning of the respiratory system have been reported in several countries and regions as a result of contact with poisonous algae since the 20th century (7-9). In 1916, respiratory system symptoms were reported in patients following algal poisoning on the West Coast of Florida in the United States (8). Furthermore, in Britain in 1989, pneumonia was detected in patients after direct contact with MCs-contaminated water as a result of swimming or boating $(7,9)$. Toxic cyanobacteria present in water entertainment parks can also generate atomized microcystins that enter the respiratory tract, which is the predominant route leading to disease of the respiratory system (10). Pilotto et al (11) reported that participants exposed to $>5,000$ cyanobacteria cells/ml for $>1 \mathrm{~h}$ had a significant increase in flu-like symptoms, such as fever and skin rashes, as compared with unexposed participants over the course of 7 days (11). In lakes with a high concentration of cyanobacteria (cell surface area $>12.0 \mathrm{~mm}^{2} / \mathrm{ml}$ ), the probability of individuals developing 
respiratory symptoms is 2.1 times that of individuals who are exposed to a low concentration of cyanobacteria (cell surface area $<2.4 \mathrm{~mm}^{2} / \mathrm{ml}$ ) (12). Water-based recreational activities can expose participants to low concentrations of microcystins via the aerosol; Backer et al (13) recruited 104 participants planning recreational activities in a lake containing cyanobacteria, as well as a nearby cyanobacteria-free lake, and demonstrated that low levels of microcystins were detected in the blood of all participants (13).

Apoptosis is a key pathophysiological mechanism associated with pneumonia. When pneumonia occurs, pneumococci induce the apoptosis of human alveolar and bronchial epithelial cells (14). Bronchial epithelial cells are the first-line defense and are therefore the first cells to be damaged (15). The damage and proliferation of bronchial epithelial cells has an important role in the repair and regeneration of lung tissues, pulmonary fibrosis and cancer (16-18). When bronchial epithelial cells are exposed to adverse factors, molecular events may occur, including oxidative stress, damage of genes, activation of proto-oncogenes or the inhibition of tumor suppressor genes in cells. These events may subsequently alter the expression levels of apoptosis-regulatory genes, leading to proliferation or damage and malignant transformation of alveolar epithelial cells, culminating in their development into lung cancer cells $(19,20)$.

Several studies have proposed that MC-LR induces apoptosis $(21,22)$, and it has been demonstrated that oxidative stress is an important mechanism of MCs toxicity (23). Oxidative stress may be induced by the imbalance between reactive oxygen species (ROS) formation and antioxidants (24). MC-LR may cause oxidative stress by increasing intracellular ROS production and diminishing glutathione in mouse hepatocytes (25). Furthermore, it has also been reported that MC-LR is capable of inducing mitochondrial damage (26) and MC-LR has been shown to persistently decrease B-cell lymphoma-2 (Bcl-2) expression levels and increase the expression levels of $\mathrm{p} 53$, Bcl-2-associated X protein (Bax) and caspase-3 (23,27). These findings indicated that oxidative stress and mitochondrial damage have an important role in MC-LR-induced apoptosis.

In the present study, human bronchial epithelial (HBE)cells were used to assess MC-LR-induced toxicity and its potential mechanisms. Cell viability, ROS, mitochondrial membrane potential (MMP), apoptosis rate, and protein expression levels of caspase-3, caspase-9, cytochrome $c$ (Cyt $c$ ), Bax and Bcl-2 were determined to investigate MC-LR toxicity, and to explore the role of the mitochondrial pathway in MC-LR-induced apoptosis of HBE cells. The present study aimed to investigate the toxicity of MC-LR on the respiratory system.

\section{Materials and methods}

Cell culture. HBE cells were kindly provided by Dr. XiuliAn in the New York Blood Center (New York, NY, USA). Cells were maintained in RPMI 1640 medium supplemented with $10 \%$ fetal calf serum (FCS; Hyclone; GE Healthcare Life Sciences, Logan, UT, USA) at $37^{\circ} \mathrm{C}$ in an atmosphere containing $5 \% \mathrm{CO}_{2}$. When the cells reached $>90 \%$ confluence, they were trypsinized (Beyotime Institute of Biotechnology, Inc., Haimen, China) and subcultured. The cells were generally used between passages 20-30 to avoid variation.
Chemicals and reagents. MC-LR with purity of $\geq 95 \%$ was obtained from Beijing Express Technology Co., Ltd., (Beijing, China). RPMI-1640 medium, Annexin V-fluorescein isothiocyanate (FITC) /propidium iodide (PI) assay kit and trypsin were purchased from Beijing Solarbio Science \& Technology Co., Ltd., (Beijing, China). ROS Assay kit and Mitochondrial Membrane Potential Assay kit were purchased from Beyotime Institute of Biotechnology and an MTT assay kit was purchased from Sigma-Aldrich (St. Louis, MO, USA). Furthermore, rabbit anti-human caspase-3 (cat. no. KGYT0656-7), rabbit anti-human caspase-9 (cat. no. KGYT0661-7), goat anti-rabbit Cyt $c$ (cat. no. KG22230-2), rabbit anti-human Bax (cat. no. KGYT0459-7) and rabbit anti-human Bcl-2 (cat. no. KGYT0469-7) polyclonal antibodies, goat anti-rabbit horseradish peroxidase (HRP)-conjugated secondary antibodies (cat. no. KGAA35; all Nanjing KeyGen Biotech Co., Ltd., Nanjing, China) and fetal calf serum (Hangzhou Sijiqing Biological Engineering Materials Co., Ltd., Hangzhou, China) were used in the present study. HBE cells were maintained in RPMI-1640 medium supplemented with $10 \% \mathrm{FCS}$ at $37^{\circ} \mathrm{C}$ in an atmosphere containing $5 \% \mathrm{CO}_{2}$. When the cells reached $>90 \%$ confluence, they were trypsinized (Beyotime Institute of Biotechnology, Inc.) and subcultured. The cells were generally used between passages 20-30 to avoid the generation of variation. All other reagents were of analytical grade.

Cell viability assay. Cell viability was assessed by MTT assay as described previously (28). Briefly, HBE cells were seeded into 96 -well plates at a density of $1 \times 10^{4}$ cells $/ \mathrm{ml}$ and, after $24 \mathrm{~h}$, cells were treated with various concentrations of MC-LR $(1,10,20,30$ and $40 \mu \mathrm{g} / \mathrm{ml})$ for $24 \mathrm{~h}$. The cells were maintained in RPMI-1640 medium supplemented with 10\% FCS at $37^{\circ} \mathrm{C}$ in an atmosphere containing $5 \% \mathrm{CO}_{2}$. Following this, each well was supplemented with $20 \mu \mathrm{l}$ MTT solution $\left(500 \mu \mathrm{g} / \mathrm{ml}\right.$ ) and incubated at $37^{\circ} \mathrm{C}$ for $4 \mathrm{~h}$, prior to incubation with $150 \mu \mathrm{l}$ dimethyl sulfoxide at $37^{\circ} \mathrm{C}$ for $10 \mathrm{~min}$. Absorbance was measured at $490 \mathrm{~nm}$ using a microplate reader (Multiskan MK3; Thermo Electric (Shanghai) Technology Instrument Co., Ltd., Shanghai, China). $\mathrm{EC}_{50}$ was defined as the concentration of MC-LR at which $50 \%$ of cell growth was inhibited when compared with the control group.

Cell viability was also assessed following pretreatment with Z-VAD-FMK. Briefly, HBE cells were seeded into 96-well plates at a density of $1 \times 10^{4}$ cells $/ \mathrm{ml}$. The cells were grown for $24 \mathrm{~h}$ prior to treatment. After $24 \mathrm{~h}$, cells were pretreated with Z-VAD-FMK at various concentrations $(0,10,20,40,60$, $80,100,120$ and $140 \mu \mathrm{M})$ for $30 \mathrm{~min}$ prior to treatment with various concentrations of MC-LR $(2.5,5$ and $10 \mu \mathrm{g} / \mathrm{ml})$ for $24 \mathrm{~h}$. An MTT assay was performed to detect cell viability, as described for MC-LR alone.

Detection of ROS and MMP. 2',7'-dichlorofluorescein diacetate (DCFH-DA; Beyotime Institute of Biotechnology, Inc.) was used for the detection of intracellular ROS. DCFH-DA is deacetylated to DCFH, and ROS then converts DCFH into oxidized DCF, which fluoresces (29). Fluorescence intensity is proportional to oxidant production (29). JC-1 staining (Beyotime Institute of Biotechnology, Inc.) was used to detect MMP, according to the previously reported 
protocol (30). ROS and MMP levels were determined by flow cytometry (BD Accuri ${ }^{\mathrm{TM}} \mathrm{C}^{6}$ Flow Cytometer; BD Biosciences, Franklin Lakes, NJ, USA). HBE cells $\left(3 \times 10^{5}\right.$ cells $\left./ \mathrm{ml}\right)$ were seeded into 6-well plates. After $24 \mathrm{~h}$ the cells were treated with various concentrations of MC-LR $(2.5,5$ and $10 \mu \mathrm{g} / \mathrm{ml})$ for 24 and $48 \mathrm{~h}$, washed twice with phosphate buffered saline (PBS) and stained with DCFH-DA and JC-1 for $20 \mathrm{~min}$ at $37^{\circ} \mathrm{C}$ in darkness prior to washing twice with PBS.

Detection of cell apoptosis via Annexin V/PI assay. Annexin-V FITC / PI double staining assay was used to detect cell apoptosis, according to the manufacturer's protocol. HBE cells $\left(1 \times 10^{5}\right.$ cells $\left./ \mathrm{ml}\right)$ were seeded into 12 -well plates and treated with various concentrations of MC-LR $(2.5,5$ and $10 \mu \mathrm{g} / \mathrm{ml})$ for 24 and $48 \mathrm{~h}$. In addition, the cells were pretreated with $50 \mu \mathrm{M} \mathrm{zVADfmk}$ for $1 \mathrm{~h}$ prior to the addition of $10 \mu \mathrm{g} / \mathrm{ml}$ MC-LR. Cells were then washed twice with PBS and, after re-suspension in $500 \mu \mathrm{l}$ binding buffer (Nanjing KeyGen Biotech Co., Ltd.), were incubated with $5 \mu$ Annexin V-FITC and $5 \mu \mathrm{l}$ PI for $15 \mathrm{~min}$ at room temperature in darkness. The percentage of apoptotic cells was determined by flow cytometry. All experiments were repeated three times.

Western blot assay. MC-LR-treated cells were washed with PBS, lysed in lysis buffer (Beyotime Institute of Biotechnology, Inc.) for $30 \mathrm{~min}$ on ice for protein extraction, centrifuged at $12,000 \mathrm{x} \mathrm{g}$ at $4^{\circ} \mathrm{C}$ for $5 \mathrm{~min}$ and the supernatants were collected. Protein concentrations were determined using the BCA method and $\sim 40 \mu \mathrm{g}$ of extracted protein from each sample was separated by sodium dodecyl sulfate-polyacrylamide gel electrophoresis and electrophoretically transferred onto polyvinylidene difluoride membranes (Beyotime Institute of Biotechnology, Inc.) using electroblotting apparatus. Membranes were subsequently blocked in Tris-buffered saline and Tween 20 (TBS-T; Beijing ComWin Biotech Co., Ltd. Beijing, China) supplemented with 5\% non-fat milk for $2 \mathrm{~h}$ at room temperature, prior to incubation with anti-caspase-3 (1:200), anti-caspase-9 (1:200), anti-Cyt $c$ (1:200), anti-Bax (1:200) anti-Bcl-2 (1:200) and rabbit anti- $\beta$-actin (1:500; cat. no. KGAA006-2; Nanjing KeyGen Biotech Co., Ltd.) antibodies, respectively, at $4{ }^{\circ} \mathrm{C}$ overnight. Membranes were then washed three times in TBS-T (5 min each) and incubated with HRP-conjugated secondary antibody $(1: 5,000)$ for $1 \mathrm{~h}$ at room temperature. Membranes were washed three times with TBS-T for $15 \mathrm{~min}$ and visualized with chemiluminescent substrates (Beijing ComWin Biotech Co., Ltd.). The immunoreactive protein was visualized using electrochemiluminescence reagents kit (Santa Cruz Biotechnology, Inc., Dallas, TX, USA) and Image $\mathrm{J}$ version 1.49 was used to analyze the immunoblots.

Statistical analysis. Data were obtained from three independent experiments and are presented as the mean \pm standard deviation. Comparisons were performed using one-way analysis of variance following the appropriate transformation to achieve a normal distribution and equalized variance where necessary. Further to this, a Student-Newman-Keuls test was used for multiple comparison of variances with homogeneity and a Games-Howell test in variances with no homogeneity. SPSS 21.0 (SPSS, Inc., Chicago, IL, USA) was used for data

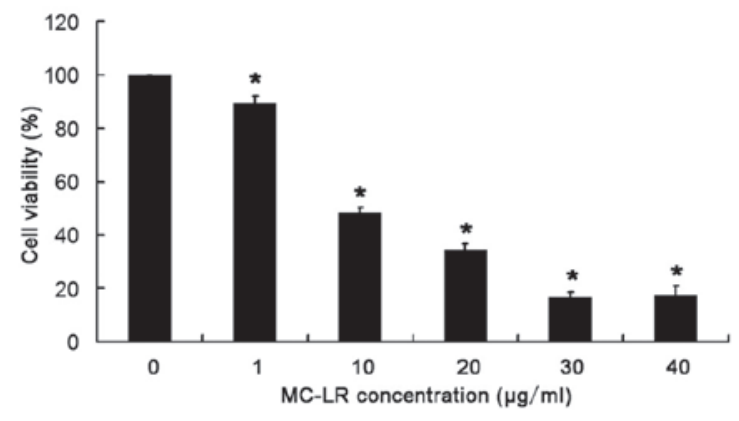

Figure 1. Human bronchial epithelial cells were exposed to various concentrations of $\operatorname{MC}-\operatorname{LR}(0,1,10,20,30$ and $40 \mu \mathrm{g} / \mathrm{ml})$ for $24 \mathrm{~h}$, and cell viability was determined using an MTT assay. Mean \pm standard deviation $(n=5)$. ${ }^{*} \mathrm{P}<0.05$ vs. control group $(0 \mu \mathrm{g} / \mathrm{ml})$. MC-LR, microcystin-LR.

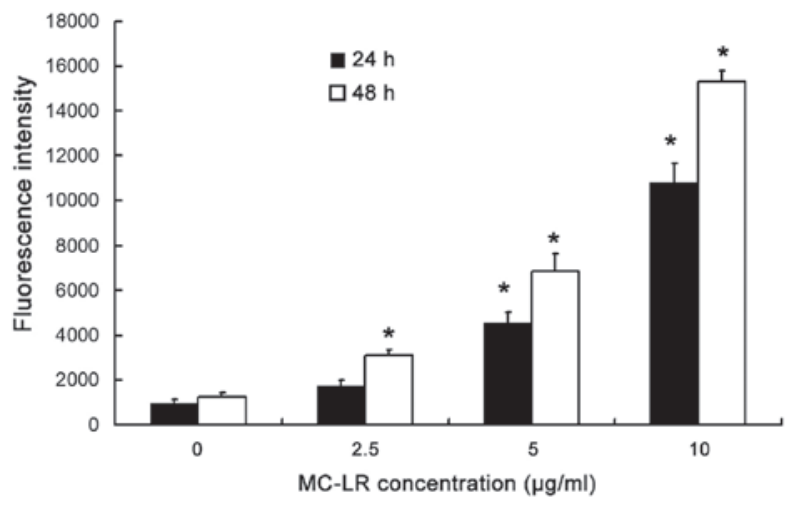

Figure 2. Flow cytometry of reactive oxygen species. Human bronchial epithelial cells were treated with various concentrations of MC-LR $(0,2.5,5$ and $10 \mu \mathrm{g} / \mathrm{ml})$ for 24 and $48 \mathrm{~h}$. ${ }^{*} \mathrm{P}<0.05 \mathrm{vs}$. control group $(0 \mu \mathrm{g} / \mathrm{ml})$. MC-LR, microcystin-LR.

analysis. $\mathrm{P}<0.05$ was considered to indicate a statistically significant difference.

\section{Results}

$M C$-LR treatment significantly decreases the viability of $\mathrm{HBE}$ cells in a concentration-dependent manner. An MTT assay was used to detect the viability of HBE cells following MC-LR treatment. As displayed in Fig. 1, cell viability reduced with the increase in MC-LR concentration, and a significant reduction in cell viability $(\mathrm{P}<0.05)$ was observed in cells after MC-LR treatment $(1,10,20,30$ and $40 \mu \mathrm{g} / \mathrm{ml})$, when compared with the control group $(0 \mu \mathrm{g} / \mathrm{ml})$. The EC50 value of MC-LR was $10 \mu \mathrm{g} / \mathrm{ml}$ in HBE cells following $24 \mathrm{~h}$ treatment. Thus, the viability of $\mathrm{HBE}$ cells significantly decreases with the increase in MC-LR concentration.

$M C$-LR treatment increases ROS production in a concentration- and time-dependent manner. ROS in HBE cells were assessed by DCF assay. As displayed in Fig. 2, when the treatment time was constant at 24 or $48 \mathrm{~h}$, ROS levels increased with the increase in MC-LR concentration, when compared with the control group ( $0 \mu \mathrm{g} / \mathrm{ml}$ MC-LR). An MC-LR concentration of 5 or $10 \mu \mathrm{g} / \mathrm{ml}$ resulted in a significant increase in the fluorescence intensity in association with the increase in treatment time $(\mathrm{P}<0.05)$. As compared with the control, 


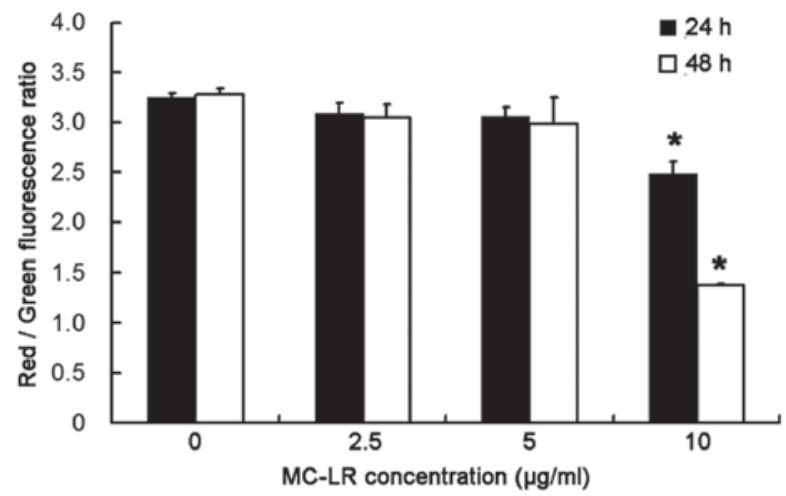

Figure 3. Flow cytometry of mitochondrial membrane potential. Human bronchial epithelial cells were treated with with various concentrations of MC-LR $(0,2.5,5$ and $10 \mu \mathrm{g} / \mathrm{ml})$ for 24 and $48 \mathrm{~h}$. Mean \pm standard deviation $(\mathrm{n}=3) .{ }^{*} \mathrm{P}<0.05$ vs. control group $(0 \mu \mathrm{g} / \mathrm{ml})$ at the same time.

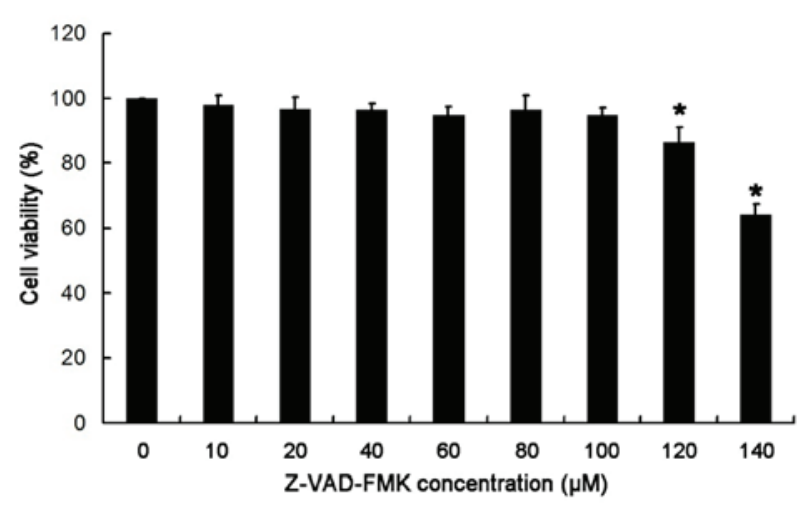

Figure 4. Human bronchial epithelial cells were pre-treated with various concentrations of Z-VAD-FMK $(0,10,20,40,60,80,100,120$ and $140 \mu \mathrm{M})$ for $24 \mathrm{~h}$, and cell viability was determined using an MTT assay. Mean \pm standard deviation ( $\mathrm{n}=5)$. ${ }^{*} \mathrm{P}<0.05$ vs. control group $(0 \mu \mathrm{M})$.

ROS increased significantly $(\mathrm{P}<0.05)$ in cells treated with $2.5 \mu \mathrm{g} / \mathrm{ml} \mathrm{MC}-\mathrm{LR}$ for $48 \mathrm{~h}$, whereas no significant change in ROS was observed following MC-LR treatment for $24 \mathrm{~h}$. Therefore, MC-LR may increase ROS production in a concentration- and time-dependent manner.

Treatment with $10 \mu \mathrm{g} / \mathrm{ml}$ MC-LR significantly decreases MMP in a time-dependent manner. To investigate the alterations in MMP following MC-LR treatment, the ratio of red:green fluorescence was determined following staining with JC-1. As demonstrated in Fig. 3, after exposure to $10 \mu \mathrm{g} / \mathrm{ml} \mathrm{MC-LR}$ for 24 and $48 \mathrm{~h}$, a significant decrease in MMP was observed in HBE cells in a time-dependent manner $(\mathrm{P}<0.05)$. Therefore, MMP in HBE cells decreases with the increase of the treatment time.

Treatment with $>100 \mu M \mathrm{Z}-V A D-F M K$ significantly reduces the viability of HBE cells. As demonstrated in Fig. 4, after treatment with Z-VAD-FMK at various concentrations $(0,10$, $20,40,60,80,100,120$ and $140 \mu \mathrm{M})$ for $24 \mathrm{~h}$, no significant difference in cell viability was observed when Z-VAD-FMK concentration were $\leq 100 \mu \mathrm{M}$; however, cell viability significantly reduced when treated with $>100 \mu \mathrm{M}$ Z-VAD-FMK $(\mathrm{P}<0.05)$ when compared with the control group $(0 \mu \mathrm{M})$. Thus,

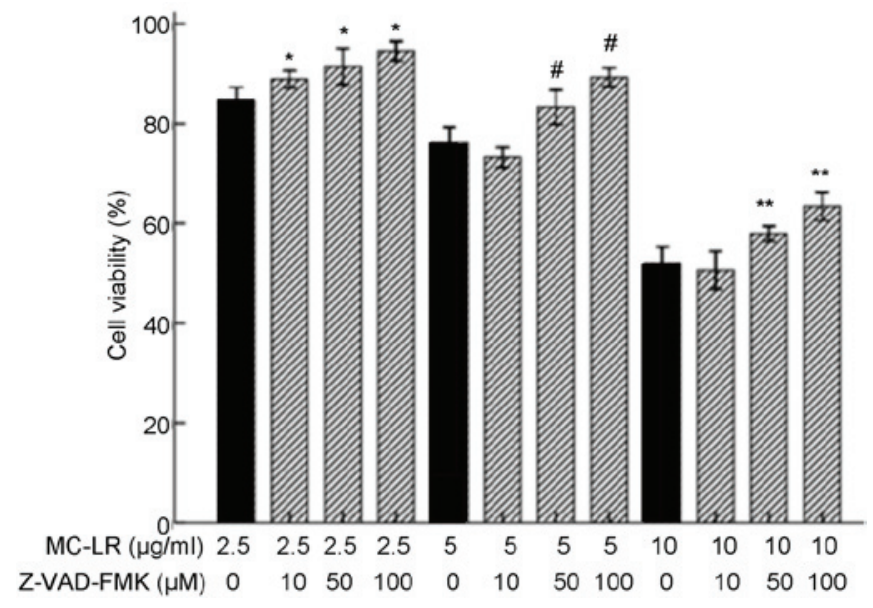

Figure 5. Human bronchial epithelial cells were treated with MC-LR (0, 2.5 , 5 and $10 \mu \mathrm{g} / \mathrm{ml})$ for $24 \mathrm{~h}$ after pretreatment with Z-VAD-FMK $(10,50$ and $100 \mu \mathrm{M}$ ) for $30 \mathrm{~min}$. Cell viability was determined using an MTT assay. Mean \pm standard deviation $(\mathrm{n}=5)$. ${ }^{*} \mathrm{P}<0.05$ vs. the respective control group at the same concentration of MC-LR. ${ }^{\text {"P }}<0.05$ vs. the respective control group at the same concentration of MC-LR. ${ }^{* *} \mathrm{P}<0.05$ vs. the respective control group at the same concentration of MC-LR. MC-LR, microcystin-LR.

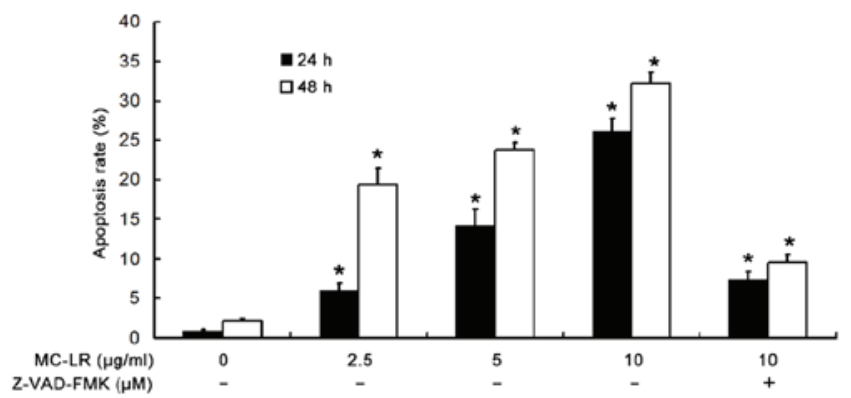

Figure 6. Cell apoptosis rate was determined by flow cytometry following Annexin-V-fluorescein isothiocyanate/propidium iodide staining. Human bronchial epithelial cells were treated with MC-LR at various concentrations for $24 \mathrm{~h}$ and $48 \mathrm{~h}$ in the presence or absence of Z-VAD-FMK pretreatment for 30 min. Mean \pm standard deviation ${ }^{*} \mathrm{P}<0.05$ vs. control group $(0 \mu \mathrm{M})$. MC-LR, microcystin-LR.

Z-VAD-FMK concentrations $\leq 100 \mu \mathrm{M}(2.5,5,10,50$ and $100 \mu \mathrm{M})$ were selected for all subsequent experiments. When the concentration of Z-VAD-FMK $>100 \mu \mathrm{M}$, the viability of HBE cells was significantly reduced.

Treatment with 50 or $100 \mu M$ Z-VAD-FMK inhibits the effect of $M C-L R$ on the viability of $H B E$ cells. The viability of HBE cells was determined by MTT assay. As demonstrated in Fig. 5, treatment with $2.5 \mu \mathrm{g} / \mathrm{ml}$ MC-LR induced significantly increased cell viability following pretreatment with 10,50 and $100 \mu \mathrm{M} \mathrm{Z-VAD-FMK}(\mathrm{P}<0.05)$ when compared with the non-pretreatment group. Treatment with 5 or $10 \mu \mathrm{g} / \mathrm{ml}$ MC-LR significantly increased cell viability following pretreatment with 50 and $100 \mu \mathrm{MZ}$-VAD-FMK $(\mathrm{P}<0.05)$, whereas a decrease was detected following pretreatment with $10 \mu \mathrm{M} \mathrm{Z}$-VAD-FMK when compared with the non-pretreatment group $(0 \mu \mathrm{M}$ Z-VAD-FMK). Therefore, $10 \mu \mathrm{M} \mathrm{Z-VAD-FMK} \mathrm{was} \mathrm{not}$ selected for use in subsequent experiments. As concentrations of 50 or $100 \mu \mathrm{M} \mathrm{Z-VAD-FMK} \mathrm{inhibited} \mathrm{the} \mathrm{effect} \mathrm{of}$ MC-LR on the viability of HBE cells, $50 \mu \mathrm{M}$ Z-VAD-FMK 
A

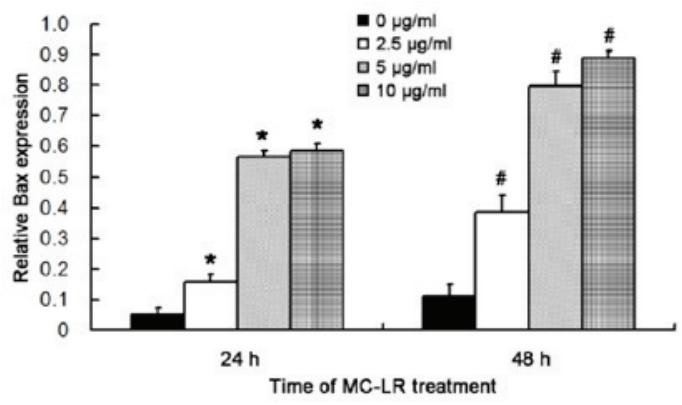

C

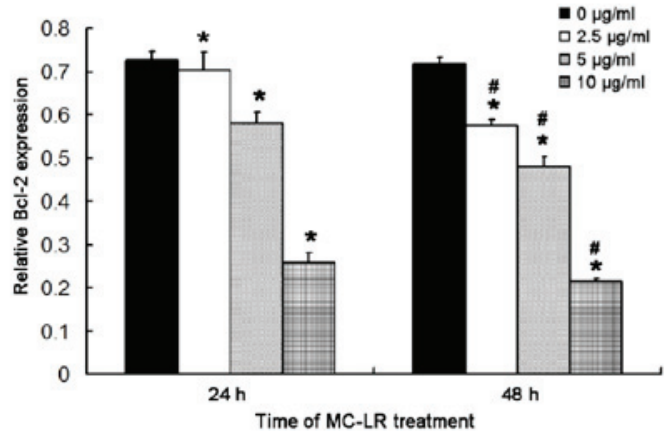

$\mathbf{E}$

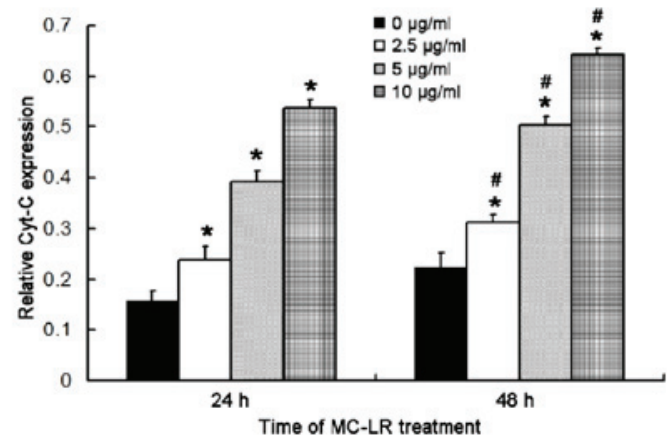

B
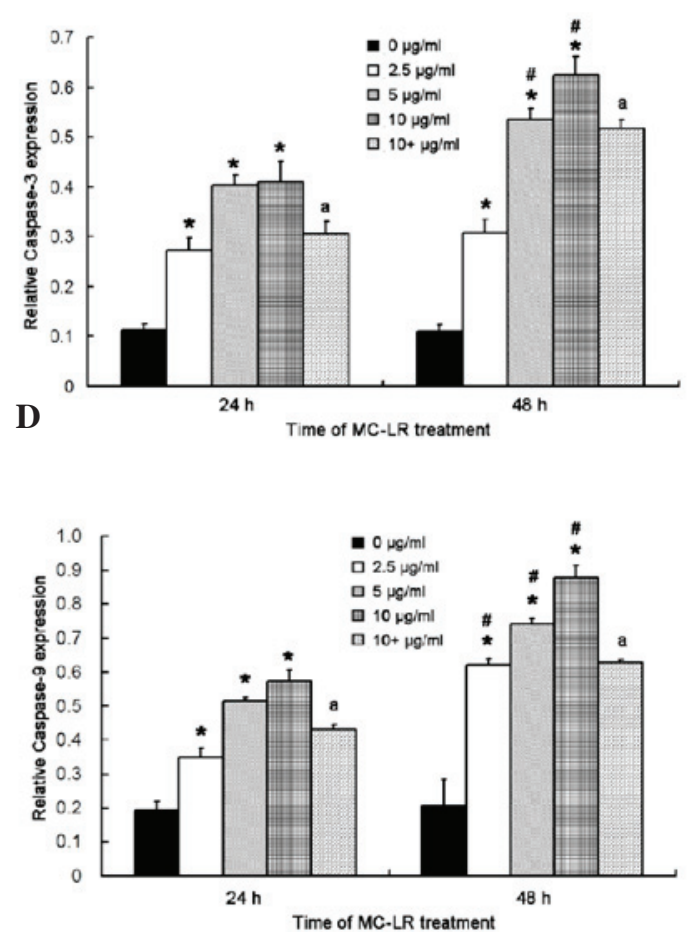

Figure 7. Effect of MC-LR and Z-VAD-FMK on the protein expression of mitochondrion-related proteins. Western blotting analysis was used to determine (A) Bax, (B) caspase-3, (C) Bcl-2, (D) caspase-9 and (E) cyt-c protein expression levels. Mean \pm standard deviation ( $\mathrm{n}=3)$. ${ }^{*} \mathrm{P}<0.05 \mathrm{vs}$. control group $(0 \mu \mathrm{g} / \mathrm{ml})$ at the same time. ${ }^{~} \mathrm{P}<0.05$ at $48 \mathrm{~h}$ vs. $24 \mathrm{~h}$ group at the same concentration. ${ }^{\mathrm{a}} \mathrm{P}<0.05 \mathrm{vs}$. control group $(10 \mu \mathrm{g} / \mathrm{ml})$ at the same time. $10+\mu \mathrm{g} / \mathrm{ml}, 10 \mu \mathrm{g} / \mathrm{ml} \mathrm{MC}-\mathrm{LR}$ group after pretreatment with $50 \mu \mathrm{M}$ Z-VAD-FMK. MC-LR, microcystin-LR; Bcl-2, B-cell lymphoma-2; cyt-c, cytochrome-c.

was selected for subsequent experiments. The viability of HBE cells exposed to MC-LR significantly increased when treated with $100 \mu \mathrm{M}$ Z-VAD-FMK and when the concentration of Z-VAD-FMK $>100 \mu \mathrm{M}$, whereas the viability of HBE cells unexposed to MC-LR was significantly reduced.

$M C$-LR treatment significantly increases the apoptotic rate of HBE cells in a time- and dose-dependent manner. To determine the apoptotic rate of HBE cells, flow cytometry was performed following Annexin V FITC and PI double staining. As demonstrated in Fig. 6, MC-LR significantly increased the apoptotic rate of HBE cells in a time- and dose-dependent manner $(\mathrm{P}<0.05)$. In addition, when MC-LR was administered at a concentration of $10 \mu \mathrm{g} / \mathrm{ml}$, the apoptotic rate was significantly inhibited by pretreatment with Z-VAD-FMK $(\mathrm{P}<0.05)$ when compared with the non-pretreatment group.

$M C$-LR treatment significantly increases the expression levels of caspase-3, caspase-9, Cyt c and Bax and reduces Bcl-2 expression. Quantification of the western blot assay indicated that the expression levels of caspase-3, caspase-9, Cyt c and Bax significantly increased in HBE cells after exposure to MC-LR for $24 \mathrm{~h}(\mathrm{P}<0.05)$, whereas $\mathrm{Bcl}-2$ expression levels significantly decreased $(\mathrm{P}<0.05)$, when compared with the control group (Fig. 7) .Expression level trends of the aforementioned proteins were consistent with those at $24 \mathrm{~h}$ when the duration of MC-LR exposure was increased to $48 \mathrm{~h}$. In addition, when HBE cells were exposed to MC-LR at the same concentration, the expression levels of caspase-3, caspase-9, Cyt $c$ and Bax increased over time, however, those of $\mathrm{Bcl}-2$ decreased, indicating a timeand concentration-dependent association. When HBE cells were exposed to MC-LR for $48 \mathrm{~h}$ at the same concentration, the expression levels of caspase-3, caspase-9, Cyt $c$ and Bax increased; however, the expression levels of Bcl-2 decreased, as compare with those of HBE cells exposed to MC-LR for $24 \mathrm{~h}$, indicating a time- and concentration-dependent association. Furthermore, pretreatment with Z-VAD-FMK significantly inhibited the expression levels of caspase-3 and caspase- 9 at 24 and $48 \mathrm{~h}$ after $(\mathrm{P}<0.05)$, when compared with the non-pretreatment group (Fig. 7B and D, respectively). 


\section{Discussion}

MC-LR is a potent inhibitor of protein phosphatase 1 and protein phosphatase 2A (31). The aforementioned phosphatases are critical regulators of embryonic development (32). Our previous in vitro studies revealed that MC-LR exerts toxic effects on Sertoli and CHO cells, which are associated with the reproductive system (27,33). In recent years, the toxicity of MCs has been investigated, and several studies have assessed the effect of MC-LR on the apoptosis of liver cells, kidney cells, cells in the lymph nodes and germ cells, in addition to the potential mechanisms of MC-LR-induced toxicity $(27,34,35)$.

It has been reported that cyanobacterial toxins may be inhaled into the body via spindrifts produced in water, which may induce respiratory diseases (26). Under these conditions, patients typically present with symptoms of the respiratory system including polypnea, cyanosis, asphyxia, which may even be fatal (8). Although previous studies have reported that MCs are capable of inducing damage to the respiratory system, little is known about the mechanism of MC toxicity to the respiratory system $(8,26)$. In the present study, HBE cells were used to investigate MC toxicity and its potential mechanism.

It is well-established that ROS and oxidative stress may trigger an apoptotic cascade (36). Previous studies have suggested that MC-LR may induce excessive ROS production $(37,38)$. For example, Chen et al (37) demonstrated that MC-LR is able to damage mitochondrial respiratory chains and oxidative phosphorylation systems by inducing ROS formation and oxidative stress. The effects of MC-LR on ROS generation are dependent on time and concentration, and $\mathrm{N}$-acetylcysteine significantly decreases MC-LR-induced ROS generation (38). Ding et al (39) reported significant and rapid increases in ROS production and the apoptosis of hepatocytes following MC-LR treatment, indicating that ROS have a critical role in MC-LR-induced apoptosis. The results of the present study demonstrated that ROS production increased with increasing MC-LR concentration, and that when the MC-LR concentration was constant, ROS increased over time, suggesting a concentration and time-dependent association. These findings indicated that MC-LR may induce ROS generation and oxidative stress in HBE cells, resulting in their apoptosis.

As a key process for eliminating unwanted or defective cells, apoptosis is an orderly process of cellular disintegration which is critical for the development and homeostasis of normal tissues. The majority of apoptotic signaling processes are associated with the alteration of apoptosis-related molecules, including $\mathrm{Bcl}-2 / \mathrm{Bax}$ and Cyt $c$ (40). Bax is a pro-apoptotic member of the Bcl-2 family which is located in the outer membrane of mitochondria (41); whereas Bcl-2 is an anti-apoptotic member of the Bcl-2 family that is present in the outer mitochondrial membrane, where it is able to suppress apoptosis via blocking Cyt $c$ release and binding to apoptotic protease-activating factor $1(42,43)$. Furthermore, previous studies have indicated that $\mathrm{Bax}$ expression is upregulated and $\mathrm{Bcl}-2$ expression is downregulated following prolonged exposure to MC-LR, and a decrease in the $\mathrm{Bcl}-2 / \mathrm{Bax}$ ratio has been revealed to be associated with apoptosis or cell death $(44,45)$. In addition, it has been demonstrated that proteins of the Bcl-2 family are able to regulate the mitochondrial apoptotic pathway (46). The results of the present study indicated that, after exposure to MC-LR for
$24 \mathrm{~h}$, the expression levels of Bax significantly increased and those of Bcl-2 significantly decreased. Following exposure to MC-LR for $48 \mathrm{~h}$, a similar change in the expression levels of the aforementioned proteins was observed. In addition, upon exposure to MC-LR at specific concentrations for 24 and $48 \mathrm{~h}$ in HBE cells, Bax expression levels increased over time whereas those of $\mathrm{Bcl}-2$ decreased. The aforementioned findings indicated that MC-LR administration may increase Bax expression and decreases $\mathrm{Bcl}-2$ expression in a time- and concentration-dependent manner.

It is widely recognized that apoptosis is initiated by two pathways, the mitochondria-mediated intrinsic pathway and the death-receptor-induced extrinsic pathway (47). Mitochondria have a key role in apoptosis and have been recognized as a central executioner, releasing apoptotic factors including Cyt $c$ and apoptosis-inducing factors (48). In cases of mitochondrial dysfunction, the mitochondrial permeability transition pores open and Cyt $c$ is released from the mitochondria to the cytosol (49). The release of Cyt $c$ from the mitochondrion has a crucial role in the apoptotic pathway, as Cyt $c$ may stimulate the formation of apoptotic bodies and subsequently activate caspase- 9 which activates caspase-3. Caspase-3 activation results in the destruction of target cells (50) and it has been demonstrated that caspase- 3 also participates in the process of MC-induced apoptosis (51). Zhang et al (46) reported that MC-LR stimulated hepatocytes to release Cyt $c$, which subsequently increased the protein expression levels of Bax, caspase- 3 and caspase- 9 and inhibited Bcl-2 expression over time via the mitochondrial pathway. Previous studies have demonstrated that caspase-3 is closely associated with apoptosis due to its ability to induce morphological changes in several types of cells (52-54). The results of the present study demonstrated that the expression levels of caspase-3, caspase-9 and Cyt $c$ increased after exposure to MC-LR for $24 \mathrm{~h}$. Following exposure to MC-LR for $48 \mathrm{~h}$, similar proteins expression trends were observed. In addition, at specific concentrations of MC-LR, the expression of caspase-3, caspase-9 and Cyt $c$ increased over time. The aforementioned findings indicated that MC-LR is capable of increasing the expression levels of caspase-3, caspase-9 and Cyt $c$ in a time- and concentration-dependent manner. Furthermore, the present study also demonstrated the apoptotic rate of HBE cells and the expression levels of caspase- 3 and caspase- 9 were inhibited following MC-LR treatment when cells underwent pretreatment with Z-VAD-FMK.

In conclusion, the present study investigated the effects of MC-LR on HBE cells and explored the potential mechanism underlying MC-LR-induced apoptosis. The results suggested that MC-LR inhibits proliferation, increases ROS generation, reduces membrane potential and induces apoptosis of HBE cells in a dose- and time-dependent manner. In addition, it was demonstrated that the MC-LR-induced apoptosis of HBE cells may be associated with the mitochondria-dependent apoptotic pathway. Notably, the present study suggested that pretreatment with Z-VAD-FMK may attenuate the adverse effects of MC-LR in HBE cells, although further studies are required in order to fully elucidate the underlying mechanism. A further understanding of the effects of Cyt $c$ and Bcl-2/Bax in caspase activation pathways is required in order to fully elucidate the mechanism underlying respiratory toxicity induced by MC-LR. 


\section{Acknowledgements}

The present study was supported by the National Natural Science Foundation of China (grant no. 81472948) and the Scientific and Technological Project of Henan Province (grant no. 142102310344) and the Program of Science and Technology Development of Henan province (grant no. 122102310208).

\section{References}

1. Wood R: Acute animal and human poisonings from cyanotoxin exposure - a review of the literature. Environ Int 91: 276-282, 2016.

2. Chen DN, Zeng J, Wang F, Zheng W, Tu WW, Zhao JS and $\mathrm{Xu}$ J: Hyperphosphorylation of intermediate filament proteins is involved in microcystin-LR-induced toxicity in HL7702 cells. Toxicol Lett 214: 192-199, 2012.

3. Zhou Y, Chen Y, Yuan M, Xiang Z and Han X: In vivo study on the effects of microcystin-LR on the apoptosis, proliferation and differentiation of rat testicular spermatogenic cells of male rats injected i.p. with toxins. J Toxicol Sci 38: 661-670, 2013.

4. Christen V, Meili N and Fent K: Microcystin-LR induces endoplasmatic reticulum stress and leads to induction of $\mathrm{NF \kappa B}$ interferon-alpha, and tumor necrosis factor-alpha.Environ Sci Technol 47: 3378-3385, 2013

5. Carmichael WW, Azevedo SM, An JS,Molica RJ, Jochimsen EM, Lau S, Rinehart KL, Shaw GR and Eaglesham GK: Human fatalities from cyanobacteria: Chemical and biological evidence for cyanotoxins. Environ Health Perspect 109: 663-668, 2001.

6. Oliveira VR, Mancin VG, Pinto EF, Soares RM, Azevedo SM, Macchione M, Carvalho AR and Zin WA: Repeated intranasa exposure to microcystin-LR affects lungs but not nasal epithelium in mice. Toxicon 104: 14-18, 2015.

7. Duy TN, Lam PK, Shaw GR and Connell DW: Toxicology and risk assessment of freshwater cyanobacterial (blue-green algal) toxins in water. Rev Environ Contam Toxicol 163: 113-185, 2000.

8. Giannuzzi L, Sedan D, Echenique R and Andrinolo D: An acute case of intoxication with cyanobacteria and cyanotoxins in recreational water in Salto Grande Dam, Argentina. Mar Drugs 9: 2164-2175, 2011

9. Turner PC, Gammie AJ, Hollinrake K and Codd GA: Pneumonia associated with contact with cyanobacteria. BMJ 300: 1440-1441, 1990.

10. Backer LC, McNeel SV, Barber T, Kirkpatrick B, Williams C, Irvin M, Zhou Y, Johnson TB, Nierenberg K, Aubel M, et al: Recreational exposure to microcystins during algal blooms in two California lakes. Toxicon 55: 909-921, 2010.

11. Pilotto LS, Douglas RM, Burch MD, Cameron S, Beers M, Rouch GJ, Robinson P, Kirk M, Cowie CT, Hardiman S, et al: Health effects of exposure to cyanobacteria (blue-green algae) during recreational water-related activities. Aust N Z J Public Health 21: 562-566, 1997.

12. Stewart I, Webb PM, Schluter PJ, Fleming LE, Burns JW Jr, Gantar M, Backer LC and Shaw GR: Epidemiology of recreational exposure to freshwater cyanobacteria - an international prospective cohort study. BMC Public Health 6: 93, 2006.

13. Backer LC, Carmichael W, Kirkpatrick B, Williams C, Irvin M, Zhou Y, Johnson TB, Nierenberg K, Hill VR, Kieszak SM and Cheng YS: Recreational exposure to low concentrations of microcystins during an algal bloom in a small lake. Mar Drugs 6: 389-406, 2008.

14. Schmeck B, Gross R, N'Guessan PD, Hocke AC, Hammerschmidt S, Mitchell TJ, Rosseau S, Suttorp N, and Hippenstiel S: Streptococcus pneumoniae-induced caspase 6-dependent apoptosis in lung epithelium. Infect Immun 72: 4940-4947, 2004.

15. Walsh GM, Sexton DW and Blaylock MG: Corticosteroids, eosinophils and bronchial epithelial cells: New insights into the resolution of inflammation in asthma. J Endocrinol 178: 37-43, 2003.

16. Li L, Qiu P, Chen B, Lu Y, Wu K, Thakur C, Chang Q, Sun J and Chen F: Reactive oxygen species contribute to arsenic-induced EZH2 phosphorylation in human bronchial epithelial cells and lung cancer cells. Toxicol Appl Pharmacol 276: 165-170, 2014.
17. Myerburg MM, Latoche JD, McKenna EE, Stabile LP, Siegfried JS, Feghali-Bostwick CA and Pilewski JM: Hepatocyte growth factor and other fibroblast secretions modulate the phenotype of human bronchial epithelial cells. Am J Physiol Lung Cell Mol Physiol 292: L1352-L1360, 2007.

18. Gao W, Li L, Wang Y, Zhang S, Adcock IM, Barnes PJ, Huang M and Yao X: Bronchial epithelial cells: The key effector cells in the pathogenesis of chronic obstructive pulmonary disease? Respirology 20: 722-729, 2015.

19. Chen DJ, Xu YM, Du JY, Huang DY and Lau AT: Cadmium induces cytotoxicity in human bronchial epithelial cells through upregulation of eIF5A1 and NF-kappaB. Biochem Biophys Res Commun 445: 95-99, 2014.

20. Yoon DH, Lim MH, Lee YR,Sung GH, Lee TH, Jeon BH, Cho JY, Song WO, Park H, Choi S and Kim TW: A novel synthetic analog of Militarin, MA-1 induces mitochondrial dependent apoptosis by ROS generation in human lung cancer cells. Toxicol Appl Pharmacol 273: 659-671, 2013.

21. Alverca E, Andrade M, Dias E, Sam Bento F, Batoréu MC, Jordan P, Silva MJ and Pereira P: Morphological and ultrastructural effects of microcystin-LR from Microcystis aeruginosa extract on a kidney cell line. Toxicon 54: 283-294, 2009.

22. Huang X, Chen L, Liu W, Qiao Q, Wu K, Wen J, Huang C, Tang R amd Zhang X: Involvement of oxidative stress and cytoskeletal disruption in microcystin-induced apoptosis in CIK cells. Aquat Toxicol 165: 41-50, 2015

23. Li L, Xie P and Guo L: Antioxidant response in liver of the phytoplanktivorous bighead carp (Aristichthys nobilis) intraperitoneally-injected with extracted microcystins. Fish Physiol Biochem 36: 165-172, 2010.

24. Turrens JF: Mitochondrial formation of reactive oxygen species. J Physiol 552: 335-344, 2003.

25. Ding WX and Nam Ong C: Role of oxidative stress and mitochondrial changes in cyanobacteria-induced apoptosis and hepatotoxicity. FEMS Microbiol Lett 220: 1-7, 2003.

26. Zhao Y, Xie P, Tang R, Zhang X, Li L and Li D: In vivo studies on the toxic effects of microcystins on mitochondrial electron transport chain and ion regulation in liver and heart of rabbit. Comp Biochem Physiol C Toxicol Pharmacol 148: 204-210, 2008.

27. Zhang HZ, Zhang FQ, Li CF, Yi D, Fu XL and Cui LX: A cyanobacterial toxin, microcystin-LR, induces apoptosis of sertoli cells by changing the expression levels of apoptosis-related proteins. Tohoku J Exp Med 224: 235-242, 2011.

28. Shah P,Djisam R, Damulira H, Aganze A and Danquah M:Embelin inhibits proliferation, induces apoptosis and alters gene expression profiles in breast cancer cells. Pharmacol Rep: 68: 638-644, 2016.

29. Afri M, Frimer AA and Cohen Y: Active oxygen chemistry within the liposomal bilayer. Part IV: Locating 2',7'-dichlorofluorescein (DCF), 2',7'-dichlorodihydrofluorescein (DCFH) and 2',7'-dichlorodihydrofluorescein diacetate (DCFH-DA) in the lipid bilayer. Chem Phys Lipids 131: 123-133, 2004.

30. Helm A, Lee R, Durante M and Ritter S: The Influence of C-Ions and X-rays on human umbilical vein endothelial cells. Front Oncol 6: 5, 2016.

31. MacKintosh C, Beattie KA, Klumpp S, Cohen P and Codd GA: Cyanobacterial microcystin-LR is a potent and specific inhibitor of protein phosphatases 1 and $2 \mathrm{~A}$ from both mammals and higher plants. FEBS Lett 264: 187-192, 1990.

32. Kawamoto M,Fujiwara A and Yasumasu I: Changes in the activities of protein phosphatase type 1 and type $2 \mathrm{~A}$ in sea urchin embryos during early development. Dev Growth Differ 42: 395-405, 2000.

33. Xue L, Li J, Li Y, Chu C, Xie G, Qin J, Yang M, Zhuang D, Cui L, Zhang $\mathrm{H}$ and $\mathrm{Fu} \mathrm{X}$ : N-acetylcysteine protects Chinese Hamster ovary cells from oxidative injury and apoptosis induced by microcystin-LR. Int J Clin Exp Med 8: 4911-4921, 2015.

34. Rymuszka A: Microcystin-LR induces cytotoxicity and affects carp immune cells by impairment of their phagocytosis and the organization of the cytoskeleton. J Appl Toxicol 33: 1294-1302, 2013.

35. Sun Y, Meng GM, Guo ZL and Xu LH: Regulation of heat shock protein 27 phosphorylation during microcystin-LR-induced cytoskeletal reorganization in a human liver cell line. Toxicol Lett 207: 270-277, 2011.

36. Vyssokikh MY, Antonenko YN, Lyamzaev KG, Rokitskaya TI and Skulachev VP: Methodology for use of mitochondria-targeted cations in the field of oxidative stress-related research. Methods Mol Biol 1265: 149-159, 2015.

37. Chen L, Zhang X, Zhou W, Qiao Q, Liang H, Li G, Wang J and Cai F: The interactive effects of cytoskeleton disruption and mitochondria dysfunction lead to reproductive toxicity induced by microcystin-LR. PloS One 8: e53949, 2013. 
38. Oh SH and Lim SC: A rapid and transient ROS generation by cadmium triggers apoptosis via caspase-dependent pathway in HepG2 cells and this is inhibited through $\mathrm{N}$-acetylcysteine-mediated catalase upregulation. Toxicol Appl Pharmacol 212: 212-223, 2006.

39. Ding WX, Shen HM and Ong CN: Critical role of reactive oxygen species and mitochondrial permeability transition in microcystin-induced rapid apoptosis in rat hepatocytes. Hepatology 32: 547-555, 2000.

40. Zhao M, Zhang Y, Wang C, Fu Z, Liu W and Gan J: Induction of macrophage apoptosis by an organochlorine insecticide acetofenate. Chem Res Toxicol 22: 504-510, 2009.

41. Li G, Bush JA and Ho VC: p53-dependent apoptosis in melanoma cells after treatment with camptothecin. J Invest Dermatol 114: 514-519, 2000.

42. Ji YB, Ji CF and Yue L: Study on human promyelocytic leukemia HL-60 cells apoptosis induced by fucosterol. Biomed Mater Eng 24: 845-851, 2014.

43. Vander Heiden MG, Chandel NS, Williamson EK, SchumackerPT and Thompson CB: Bcl-xL regulates the membrane potential and volume homeostasis of mitochondria. Cell 91: 627-637, 1997.

44. Kim HG, Song H, Yoon DH, Song BW, Park SM, Sung GH, Cho JY, Park HI, Choi S, Song WO et al: Cordyceps pruinosa extracts induce apoptosis of HeLa cells by a caspase dependent pathway. J Ethnopharmacol 128: 342-351, 2010.

45. Wiebe JP, Beausoleil M, Zhang G and Cialacu V: Opposing actions of the progesterone metabolites, 5alpha-dihydroprogesterone (5alphaP) and 3alpha-dihydroprogesterone (3alphaHP) on mitosis, apoptosis, and expression of $\mathrm{Bcl}-2$, Bax and p21 in human breast cell lines. J Steroid Biochem Mol Biol 118: 125-132, 2010.
46. Zhang H, Cai C, Fang W, Wang J, Zhang Y, Liu J and Jia $\mathrm{X}$ : Oxidative damage and apoptosis induced by microcystin-LR in the liver of Rana nigromaculata in vivo. Aquat Toxicol 140-141: 11-18, 2013

47. Spencer SL and Sorger PK: Measuring and modeling apoptosis in single cells. Cell 144: 926-939, 2011.

48. Ferri KF and Kroemer G: Mitochondria--the suicide organelles. BioEssays 23: 111-115, 2001

49. Zhang S, Zhang Y, Zhuang Y, Wang J, Ye J, Zhang S, Wu J, Yu K and Han Y: Matrine induces apoptosis in human acute myeloid leukemia cells via the mitochondrial pathway and Akt inactivation. PLoS One 7: e46853, 2012.

50. Xiong Q, Xie P, Li H, Hao L, Li G, Qiu T and Liu Y: Involvement of Fas/FasL system in apoptotic signaling in testicular germ cells of male Wistar rats injected i.v. with microcystins. Toxicon 54: 1-7, 2009.

51. Fladmark KE, Brustugun OT, Hovland R, Boe R, Gjertsen BT, Zhivotovsky B and Døskeland SO: Ultrarapid caspase-3 dependent apoptosis induction by serine/threonine phosphatase inhibitors. Cell Death Differ 6: 1099-1108, 1999.

52. Hirata H, Takahashi A, Kobayashi S, Yonehara S, Sawai H, Okazaki T, Yamamoto K and Sasada M: Caspases are activated in a branched protease cascade and control distinct downstream processes in Fas-induced apoptosis. J Exp Med 187: 587-600, 1998.

53. Jänicke RU, Sprengart ML, Wati MR and Porter AG: Caspase-3 is required for DNA fragmentation and morphological changes associated with apoptosis. J Biol Chem 273: 9357-9360, 1998.

54. Woo M, Hakem R, Soengas MS, Duncan GS, Shahinian A, Kägi D, Hakem A, McCurrach M, Khoo W, Kaufman SA, et al: Essential contribution of caspase 3/CPP32 to apoptosis and its associated nuclear changes. Genes Dev 12: 806-819, 1998. 